\title{
Enhancing Drilling Parameters in Majnoon Oilfield
}

\author{
Majid M. Majeed and Ayad A. Alhaleem
}

University of Baghdad

\begin{abstract}
The objective of drilling parameters optimization in Majnoon oilfield is to arrive for a methodology that considers the past drilling data for five directional wells at 35 degree of inclination as a baseline for new wells to be drilled. Also, to predicts drilling performance by selecting the applied drilling parameters generated the highest rate of penetration (ROP) at each section. The focal point of the optimization process is to reduce drilling time and associated cost per each well. The results of this study show that the maximum ROP could not be achieved without sufficient flow rate to cool and clean the bit in clay intervals (36" and 24") hole sections. Although the influence of combination of Weight on Bit (WOB), Round per minute (RPM), and hydraulic horsepower on the bit in (16", 12 1/4" and $81 / 2 ")$ hole sections is a key to reduce drilling time, therefore, the drilling parameters produced the fastest ROP per each section was considered as optimum parameters likely to apply for the future wells.
\end{abstract}

Keywords: Drilling parameters, Drilling time, Weight on bit, Rate of penetration

Received on 02/09/2018, Accepted on 18/12/2018, published on 30/06/2019

https://doi.org/10.31699/IJCPE.2019.2.9

\section{1- Introduction}

Proper planning of any drilling project is the key to optimizing operations and minimizing expenditures. Therefore the first step in planning a well should be the gathering of all available data from the past wells, in this respect, it is essential to be completely familiarized with all sources of information, the availability of data, and the information normally associated per each section [1].

Drilling optimization is normally characterized by the Rate of penetration (ROP), where several parameters contribute towards the ROP such as Weight on the bit (WOB), Round per minute (RPM), Flow rate, Hydraulics and bit type [2].

One of the attempts for drilling optimization purpose was presented by David Hankins (2014) where the author gathered data from preexisting wells that were drilled within the same field, necessary data includes bit records, operational drilling parameters and lithological information encountered during drilling. The preexisting data is crucial since it is used to predict the results of different drilling scenarios when planning new wells, as it will be used as a reference for the upcoming wells. Therefore there is no major difference between the plan and the actual drilling time [3].

Majnoon oilfield is a super-giant oil field located $60 \mathrm{~km}$ from Basrah city in southern Iraq. Majnoon is one of the richest oil fields in the world with an estimated 38 billion barrels of oil in place in multiple reservoirs; the field was named Majnoon, which means 'crazy' in Arabic in reference to the dense accumulation of oil in the area.
Several directional wells have been drilled in Majnoon oil field to produce from different reservoirs such as Mishrif, Nahr-Umer, and Zubair pay zones, in order to increase the production of the field [4].

Many research studies have been performed for the optimization of drilling operation having an objective to optimize footage drilled and minimize drilling cost. Therefore a massive amount of data were collected and analyzed from offset wells drilled in the Majnoon oilfield including bit types, Mud type, WOB, RPM, and flow rate as well as lithological column encountered during drilling for five directional wells at 35 degree inclination.

In order to predict the drilling behavior for new wells, the drilling time per each hole section must be considered to find the best operating drilling parameters. Based on each hole section comparisons of the drilled wells, the optimum drilling parameters was considered.

\section{2- Well Design}

The wells in the Majnoon oil field were drilled either to Mishrif carbonates, Nahr-Umer Sands, or Zubair Sands. First, the top hole section is drilled across Upper Fars formation with 36 " bit to an approximately $100 \mathrm{~m}$ depth where the weak formations existed, and 30" conductor casing is cemented in place to ensure that the water table had been adequately cased-off. Second, the surface hole section is drilled to seal off the unconsolidated formations which typically consists of Clay and Sands with 24" bit to $600 \mathrm{~m}$ depth. The $185 / 8$ " surface casing is set vertically and cemented to surface and the Kick-off point designed in the next hole section at sufficient distance below the previous casing shoe depth [5]. 
Third, the intermediate section is drilled with 16" bit to $1500 \mathrm{~m}$ across Lower Fars and Ghar formations. The 13 $3 / 8$ " casing is run and cemented $150 \mathrm{~m}$ inside the previous casing. The objective is to allow the next hole section to be drilled through potential loss circulation zones without the risk of initiating a well control problem due to severe drilling fluid losses [6].

Next, is the second intermediate $121 / 4$ " section is drilled to 2500m through Dammam, Um Er Radhumma, Alaiji, shiranish, Hartha, Saadi, Tanuma, and Khassib formation. The $95 / 8$ " casing run and cemented $100 \mathrm{~m}$ inside the previous casing section, the objective is to seal off loss circulation and hydrocarbon zones.

Finally, the $81 / 2$ " production section is drilled to reach well total depth (TD) and desired reservoir zone; the 7" casing liner run and cemented $150 \mathrm{~m}$ inside the previous casing [7].

\section{3- Data Processing and Discussion}

According to the gathered necessary data from preexisting wells that were drilled in Majnoon oilfield, that includes Daily Drilling Reports (DDR), Mud logging Data, Bit records, final well Report (FWR), and lithological information encountered while drilling it is essential to forecast the drilling time per each hole section when planning new well.

Therefore there are no major discrepancies between the planned and actual drilling time. Take into considerations that the drilling time to complete every hole section was normalized to same depth reference.

The fastest ROP per each hole section was considered to find the best operating drilling parameters. In order to achieve effective drilling optimization, an extensive analysis was conducted on which parameters generate higher ROP Fig. 1 and Fig. 2.

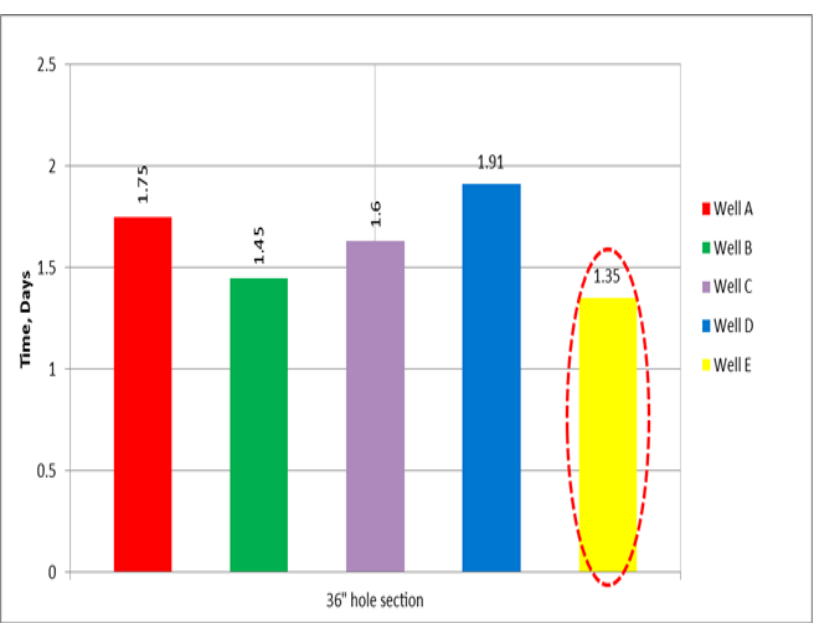

Fig. 1. 36" Hole section comparisons [8].

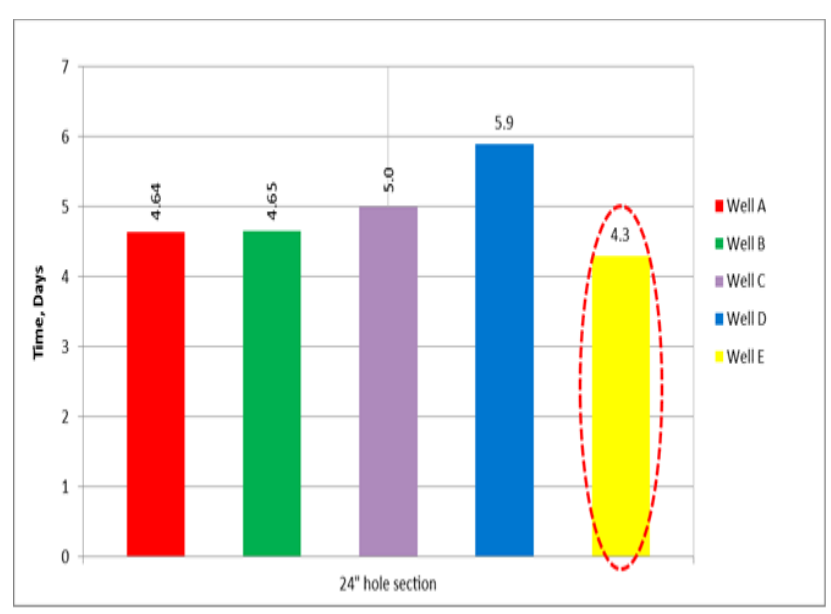

Fig. 2. 24" Hole section comparisons [8]

In well E, the 36" and 24" hole sections described in Fig. 1 and Fig. 2 respectively, identified as the fastest section drilled among the offset wells, as a result of 90 RPM, 20-30 kilo pounds (klbs) WOB, flow rate 500-900 Gallon per minute (GPM), also the use of 65,000 Parts per million (PPM) of mud salinity helped to retard the rate of clay hydration [8].

The chosen drilling mud type per each section must be designed to mitigate hole instability and drilling problems, it is also important to maintain low gravity solids and high gravity solids at a minimum level to enhance drilling performance [9].

The associated drilling parameters are shown in Fig. 3 is the best drilling parameters to use in these sections for future wells [8].

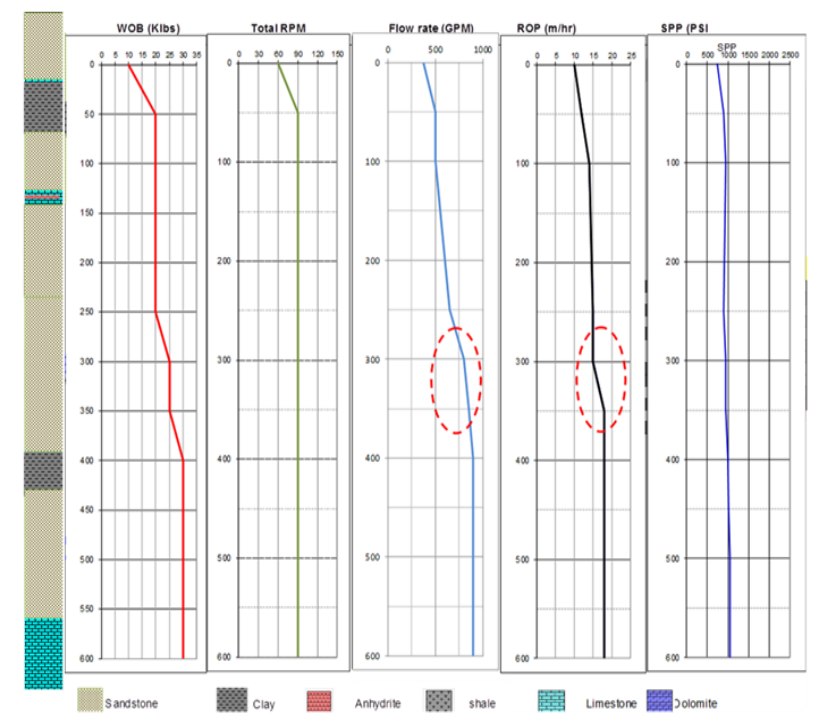

Fig. 3. Optimum drilling parameters for $36 "$ and $24 "$ hole sections [9] 
Fig. 4 clearly shows that 16 " hole section in well D is the fastest directional section drilled, this is due to successful selection of Polly crystalline diamond compact bit (PDC) type (SFD75DH) and utilized drilling parameters of WOB 15-30 klbs, RPM 120, flow rate 900 GPM generated average ROP $20 \mathrm{~m} / \mathrm{hr}$ [8].

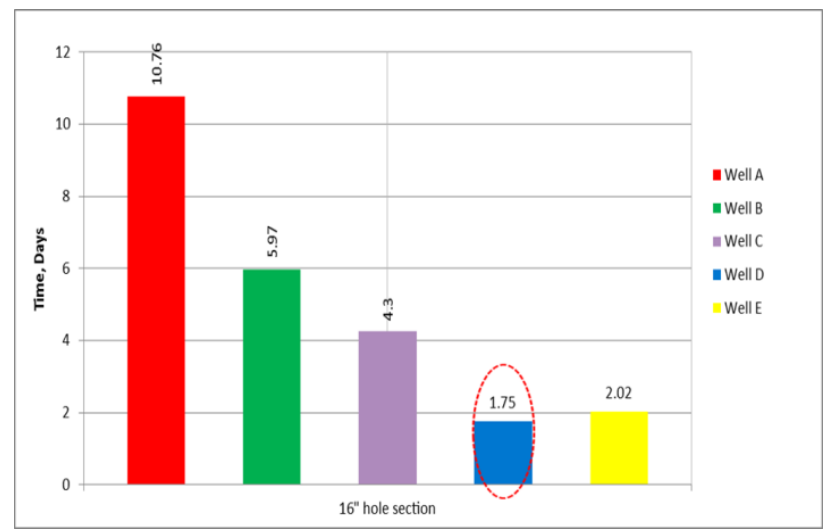

Fig. 4. 16" Hole section comparisons [8]

Fig. 5 shows the effect of increasing the RPM and Flow rate on the ROP; it clearly shows that ROP increases directly with RPM and Flow rate at sufficient HSI, although at $800 \mathrm{~m}$ depth observed ROP increases directly with WOB when RPM and Flow rate is constant.

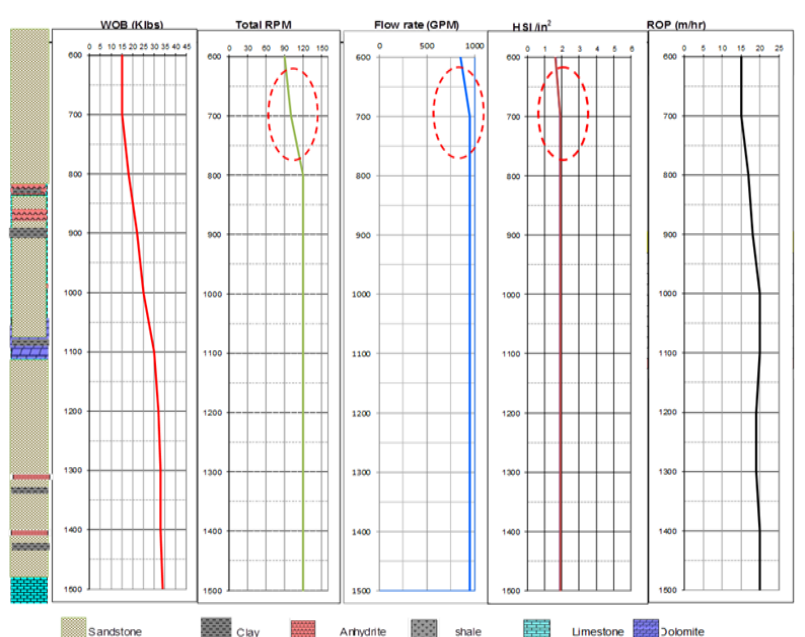

Fig. 5. Optimum drilling parameters for 16" hole section [10]

As seen in Fig. 6 that 12 1/4" hole section in well E is the fastest section drilled among the previous wells drilled, this is due to the fact of the significant value of hydraulic horsepower per square inch applied during drilling with $25 \mathrm{klbs}$ WOB, 150 RPM, and flow rate 700800 GPM. It is well deserved to use the associated drilling parameters of this section as a guideline for the future wells in order to drill wells in time efficient manner [11] as displayed in Fig. 7.

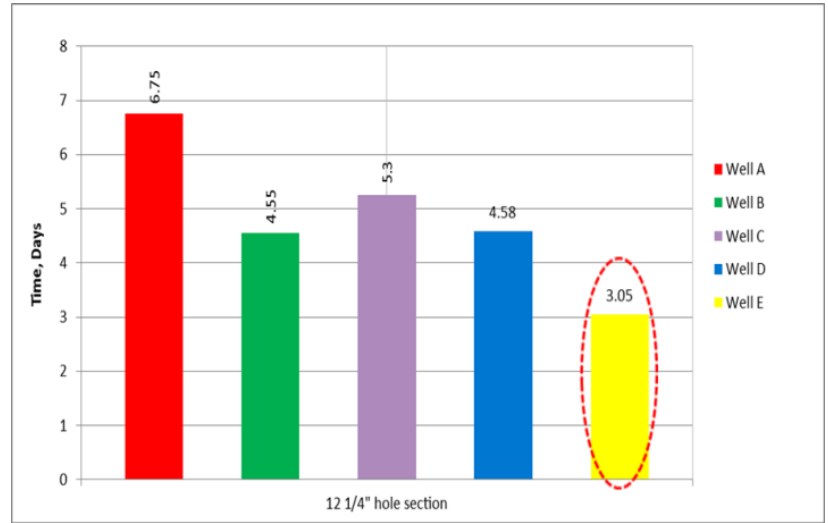

Fig. 6. 12 1/4" Hole section comparisons [8]

Fig. 7 shows the significant effect of the HSI on the ROP, the higher HSI results from the suitable nozzle selections and higher Flow rate led to impressive ROP along the entire hole section.

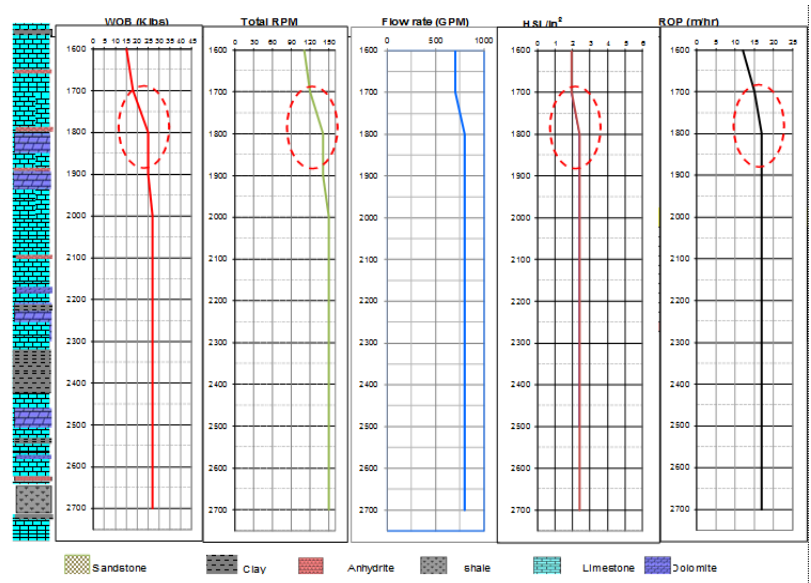

Fig. 7. Optimum drilling parameters for $121 / 4$ " hole section [10]

Fig. 8 indicates that good drilling performance was achieved during drilling $81 / 2 "$ hole section in well $\mathrm{C}$. However at $3600 \mathrm{~m}$ ROP declined from $24 \mathrm{~m} / \mathrm{hr}$ to $10 \mathrm{~m} / \mathrm{hr}$ due to severe vibrations, but ROP recovered after adding lubricants to the drilling mud where the desired drilling parameters implemented to drill the section in a short period of time compared to the previous wells drilled [11] as shown in Fig. 9.

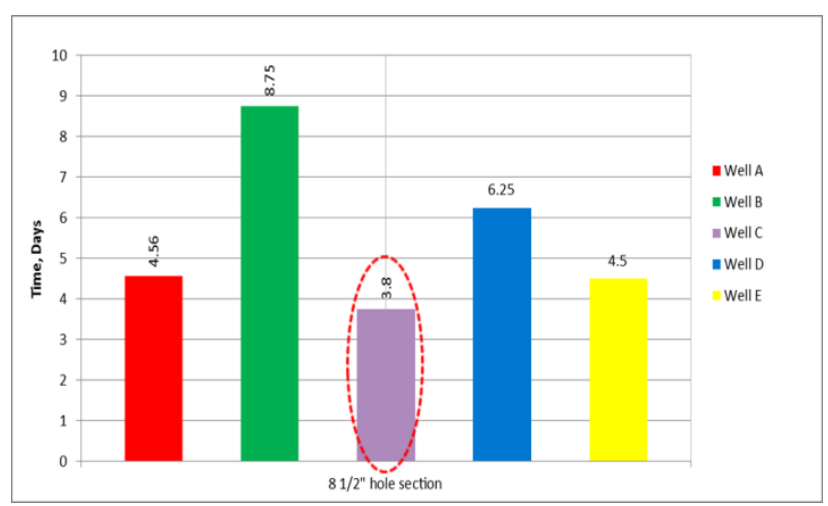

Fig. 8. 1/2" hole section comparisons [8] 
In Fig. 9 it's important to notice that started drilling with higher WOB, Flow rate and RPM resulted in remarkable ROP of $24 \mathrm{~m} / \mathrm{hr}$ until entered the Anhydrite layers at $3300 \mathrm{~m}$ depth, where the ROP declined dramatically due to severe vibrations, treatment to the drilling fluids was considered by adding lubricants and mitigated the vibrations successfully.

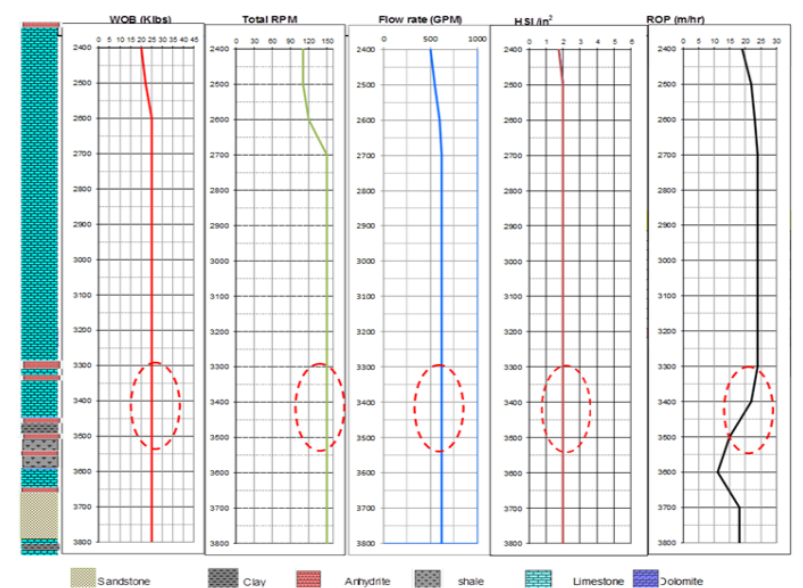

Fig. 9. Optimum drilling parameters for 8 1/2" hole section [10]

\section{4- Conclusions}

1- In the 36" and 24" hole sections for well E the major problem to overcome is the clay hydration, where the bit balling affect the ROP. Therefore the use of 65,000 PPM mud salinity with 90 RPM, 20-30 klbs WOB, and 500-900 GPM flow rate achieved constant ROP without bit balling signs during drilling.

2- The successful selection of 16" PDC bit type (SFD75DH) in well D within associated WOB of 30 klbs, 120 RPM, and flow rate 900 GPM showed incredible ROP of $20 \mathrm{~m} / \mathrm{hr}$. consequently this section was drilled in 1.75 days, which represent significant reduction in drilling time.

3- In 12 1/4" hole section of well E, hydraulic horse power of 2.5 per square inch which required for optimum hole cleaning varies directly with $25 \mathrm{klbs}$ WOB, 140 RPM, consequently, hydraulic horse power of 2.5 was sufficient to drill at $18 \mathrm{~m} / \mathrm{hr}$ ROP.

4- In well $\mathrm{C}$ While drilling 8 1/2" hole section encountered stringers of Anhydrite, ROP declined from $24 \mathrm{~m} / \mathrm{hr}$ to $10 \mathrm{~m} / \mathrm{hr}$ in short period. Hence the added of lubricants to the drilling mud enhanced the ROP and avoided the bad vibrations.

\section{Nomenclatures}

$\begin{array}{ll}\text { GPM } & \text { Gallon per minute } \\ \text { PDC } & \text { Polly crystalline diamond compact } \\ \text { PPM } & \text { Parts per million } \\ \text { ROP } & \text { Rate of penetration } \\ \text { RPM } & \text { Round per minute } \\ \text { TD } & \text { Total depth } \\ \text { WOB } & \text { Weight on bit }\end{array}$

\section{References}

[1] Richard Caredn, "Planning a well" Chapter one, Tulsa Oklahoma: OGCI Petro skills training, 2006.

[2] H. Abdul Hadi, "Correlation of Penetration Rate with Drilling Parameters For an Iraqi Field Using Mud Logging Data", ijcpe, vol. 16, no. 3, pp. 35-44, Sep. 2015.

[3] David Hankins, Saeed Salehi," An Integrated Approach of Optimizing Drilling Parameters using advanced drilling optimizer" Lafayette: Journal of Petroleum Engineering, 2014.

[4] M. M. Majeed and A. A. Alhaleem, "Selection of Suitable Drilling Parameters for obtaining high Rate of Penetration in Majnoon Oilfield", ijcpe, vol. 20, no. 1, pp. 65-68, Mar. 2019.

[5] Iraq Ministry of Oil "Iraq's second petroleum licensing Round Majnoon contract area", press release, 2009.

[6] Miguel Armenta, Rob Tinkhof, "improving drilling performance at Majnoon Oilfield", UAE: SPE/IADC drilling conference and Exhibition, 2013.

[7] Marc- Le Vesconte ," The Majnoon Field - A case study of Drilling Operations in Remote area of Iraq" Texas: SPE/ IADC Drilling conference and Exhibition, 2014.

[8] South Oil company" Final well Reports", Iraq: 2014.

[9] Nazaneen said , Ayad A. Alhaleem "Analysis of Stuck pipe incidents in Khabaz Field" University of Baghdad, IJCPE, 2018.

[10] South Oil company" Mud logging Data", Iraq: 2014.

[11] South Oil company" Bit records", Iraq: 2014. 


\section{تحسين ادائيه معاملات الحفر في حقل مجنون النفطي}

\section{الخلاصة}

الغرض من تحليل معاملا ت الحفر المستخدمه في حقل مجنون النفطي هو الوصول الى وسيله تعتبر

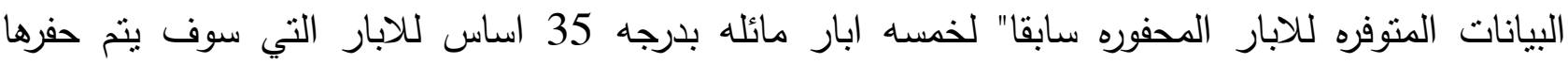

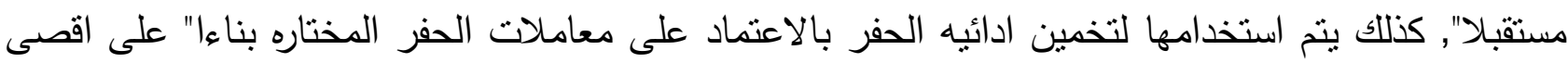
معدل اختراق لكل مقطع. الهدف الاساسي من اختيار المعاملات المثاليه اثثاء عمليه الحفر هو لتقليل الوقت المرا د به الوصول الى لى

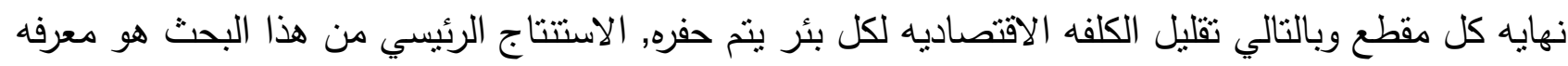
المتطلبات الاساسيه للحصول على اعلى معدل اختراق والذي لايمكن تحقيقه من غير تسليط معدل جريان

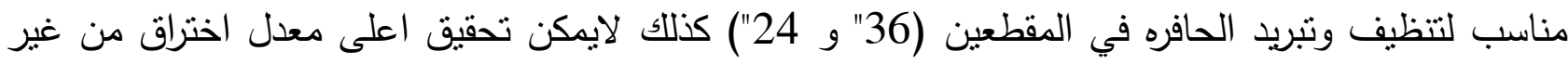

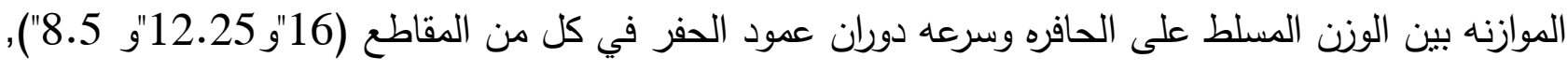

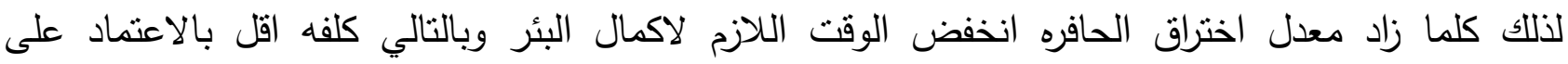

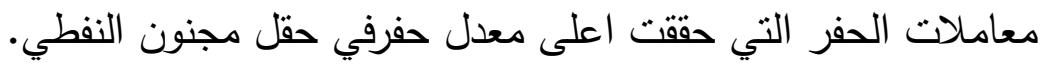

